\title{
Penerapan Tindak Pidana Malpraktik yang Menyebabkan Kematian Berdasarkan Uu No.36 Tahun 2009 Tentang Kesehatan
}

\section{The Application of Malpractic Criminal Causes Causing Death Based on Law No.36 of 2009 on Health}

\author{
Dwi Fahri Wijaya*, Marwin Sitinjak \& Aston Martin Panggabean
}

Program Studi Ilmu Hukum, Fakultas Hukum, Universitas Prima, Indonesia

Diterima: 10 Juli 2020; Disetujui: 02 Agustus 2020; Dipublish: 04 Agustus 2020

* Email: ervfahri@gmail.com

\begin{abstract}
Abstrak
Penelitian ini bertujuan untuk mengetahui Pemberlakuan sanksi pidana terhadap tenaga kesehatan berdasarkan Undang-Undang Nomor 36 Tahun 2014 tentang Tenaga Kesehatan. Dengan latar belakang masalah mengenai kebijakan hukum terhadap tindak pidana malapraktik yang dilakukan oleh dokter dalam melakukan tugasnya, dan sanksi profesi yang diberikan kepada dokter yang melakukan tindak pidana malapraktik yang menyebakan kematian. Metode penelitian yang digunakan dalam penelitian ini adalah pendekatan yuridis normatif yaitu untuk meneliti data sekunder dengan cara mengadakan penelusuran terhadap undang-undang yang dipakai dalam tindak pidana malpraktik. Penelitian ini merupakan jawaban atas latar belakang masalah yang terkait dengan malpraktik yang menyebabkan kematian Berdasarkan Undang-undang No.36 Tahun 2009 Tentang Kesehatan. Malpraktik adalah suatu tindakan-tindakan yang termasuk dalam kategori kesengajaan (intentional, dolus, opzettelijk) atau kelalaian yang melanggar undang-undang.Pemberlakuan sanksi pidana terhadap tenaga kesehatan berdasarkan Undang-Undang Nomor 36 Tahun 2014 tentang Tenaga Kesehatan terdiri dari pidana penjara dan pidana denda sesuai dengan jenis tindak yang dilakukan oleh tenaga kesehatan.
\end{abstract}

Kata kunci: Malpraktik, Sanksi Pidana, Kesehatan

\begin{abstract}
The study aims to know of the implementation of criminal sanctions against the establishment of health act no. 36 years 2014 on health care guidelines against the legal policy against malpractice crimes committed by doctors in the practice of malpractice, and the professional sanction given to doctor vang commits a malpractice that causes death. Vang research method used in this study is the conservative vuridis approach to examining secondary data by searching through laws used in malpractice crimes. This research is the answer to the background of the problems associated with malpractice that Causing death under statute no.36 years 2009 about Health. Malpractice is an offense (intentional, dolus, opzettelijk) or negligence in violation of the law, the enforcement of criminal penalties against health powers by law: the 36-year 2014 law on health power consists of prison crime and penal penalties in accordance with the type of ACTS committed by health workers.

Keywords: Malpractice, Criminal sanction, Health

How to Cite: Wijaya, D.F, Sitinjak, M. \& Panggabean, A.M. (2020). Penerapan Tindak Pidana Malpraktik Yang Menyebabkan Kematian Berdasarkan Uu No.36 Tahun 2009 Tentang Kesehatan. Journal of Education, Humaniora and Social Sciences (JEHSS). 3(1): 147-152.
\end{abstract}




\section{PENDAHULUAN}

Bangsa indonesia mempunyai cita-cita sebagaimana tercantum dalam pembukaan Undangundang Dasar Negara Republik Indonesia Tahun 1945 adalah melindungi segenap bangsa indonesia dan seluruh tumpah darah indonesia dan untuk memajukan kesejahteraan umum, mencerdaskan kehidupan bangsa dan ikut melaksanakan ketertiban dunia yang berdasarkan kemerdekaan, perdamaian abadi, dan keadilan sosial. Kesehatan sebagai salah satu unsur kesejahteraan umum harus mewujudkan melalui berbagai upaya kesehatan secara menyeluruh dan terpadu.

Tindak pidana merupakan terjemahan dari "strafbaar feit" yaitu perbuatan yang dilarang oleh suatu aturan hukum larangan dengan mana disertai ancaman (sanksi) yang berupa pidana tertentu, bagi barang siapa yang melanggar larangan tersebut. Kitab Undang - Undang Hukum Pidana tidak terdapat penjelasan mengenai apa sebenarnya yang dimaksud dengan strafbaar feit itu sendiri. Tindak pidana biasanya disamakan dengan delik, yang berasal dari bahasa latin yakni kata delictum. Delik tercantum dalam Kamus Besar Bahasa Indonesia sebagai berikut : "Delik adalah perbuatan yang dapat dikenakan hukuman karena merupakan pelanggaran terhadap Undang - Undang tindak pidana"

Berdasarkan undang-undang 36 Tahun 2009 tantang Kesehatan menyebutkan bahwa kesehatan adalah keadaan keadaan sejahtera dari badan, jiwa, dan sosial yang memungkinkan setiap orang hidup produktif secara rasional dan ekonomis.dimana kesehatan selain sebagai hak asasi manusia, kesehatan juga merupakan suatu investasi. Dalam pasal 34 ayat (3) undang- undang dasar 1945 dinyatakan bahwa negara bertanggung jawab atas penyediaan fasilitas pelayanan umum yang layak. Hal ini menunjukkan bahwa pemerintah berkewajiban untuk meyehatkan yang sakit dan berupaya mempertahankan yang sehat untuk tetap sehat.

Hukum kedokteran, sebagai bagian dari hukum kesehatan yang terpenting, meliputi ketentuan hukum yang berhubungan dengan pelayanan medis hukum kedokteran disebut juga hukum kesehatan dalam arti sempit apabila objek hukum kesehatan yung pelayan kesehatan, maka objek hukum kedokteran adalah pelayanan medis oleh karena pengertian hukum kesehatan lebih luas dari hukum kedokteran dan juga meliputi ketentuan-ketentuan hukum yang berhubungan dengan pemeliharaan kesehatan. Hukum kedokteran bagian terpenting karena hampir selalu terdapat persinggungan atau daerah-daerah kelabu antara hukum kedokteran dan bidang-bidang hukum lainnya.

Peraktik kedokteran mengombinasikan sains dan seni, sanis dan teknologi adalah bukti dasar atas berbagai masalah klinis dalam masyarakat. Seni kedokteran adalah penerapan gabungan antara ilmu kedokteran, intuisi, dan keputusan medis untuk menentukan diagnosis yang tepat dan perencanaan perawatan untuk masing-masing pasien pasien serta merawa pasien sesuai dengan apa yang di perlukan olehnya peraktik kedokteran di bentuk untuk melindungi masyarakat penerima jasa palayanan kesehatan dan meningkatkan mutu pelayanan kesehatan dari dokter. Aturan hukum yang mengatur masalah kesalahan dokter secara nyata, dalam melaksanakan perawatannya, lebih banyak di hasilkan oleh putusan pengadilan. Di indonesia sendiri putusan-putusan yang mengadili kesalahan dokter belumlah banyak apakah itu malapraktik yang menyebabkan kematian oleh karna itu, perlu di tinjau dahulu masalah yurisprudensi sebagai salah satu sumber hukum .

Dalam Kelalaian medis dapat di persalahkan, sedangkan pada kecelakaan medis tidak dapat di persalahkan, asalkan kecelakan ini merupakan kecelakaan murni, dimana tidak ada unsur kelalaiannya. Hal ini disebabkan karena didalam hukum medis yang terpenting bukanlah akibatnya, tetapi cara bagaimana sampai terjadinya akibat itu, bagaimana tindakan itu dilakukan. Inilah yang paling penting di ketahui (Abidin, dkk., 2019; Lasminar, dkk., 2014; Afwina, 2019). Untuk itu dipakailah tolak ukur yaitu etik kedokteran standart profesi medis sebagaimana diketahui hukum pidana pertama-tama melihat dahulu akibat yang ditimbulkan, baru motif dari tindakan tersebut. Setiap orang yang mengetahui atau kepentinganya dirugikan atas tindakan dokter dalam menjalankan praktik kedokteran dapat mengadukan secara tertulis kepada ketua Majiles Kehormatan Disiplin Kedokteran Indonesia. 


\section{METODE PENELITIAN}

Jenis penelitian yang digunakan adalah pendekatan yuridis normatif yaitu metode penelitian hukum yang dilakukan dengan meneliti berdasarkan bahan hukum utama dengan cara menelaah konsep- konsep, teori-teori, asas-asas hukum serta peraturan perundang-undangan yang berhubungan dengan penelitian ini. Metode pendekatan ini dikenal pula dengan metode kepustakaan, yakni dengan mempelajari buku- buku, peraturan perundang-undangan dan dokumen lain yang berhubungan dengan penelitian ini, Sumber data yang digunakan adalah sumber data sekunder, yang terdiri dari bahan hukum primer, bahan hukum sekunder dan bahan hukum tersier.

\section{HASIL DAN PEMBAHASAN \\ Kebijakan Hukum Terhadap Tindak Pidana Malpraktik yang Dilakukan Oleh Dokter Dalam Menjalankan Tugasnya}

Istilah kebijakan diambil dari kata "policy" atau kata "politiek" istilah kebijakan hukum pidana dan dapat juga disebut dengan istilah politik hukum pidana. kebijakan atau politik hukum pidana dapat dilihat dari politik hukum atau dari politik hukum kriminal. Menurut Sudarto, politik hukum adalah Usaha untuk mewujudkan suatu peraturan-peraturan yang baik sesuai dengan keadaan dan situasi pada suatu saat. Usaha dan kebijakan untuk membuat peraturan hukum pidana yang baik dan benar, pada hakikatnya tidak dapat di lepaskan dari tujuan penanggulangan kejahatan. Maksud kebijakan atau hukum politik hukum pidana identik dengan pengertian kebijakan penanggulangan kejahatan dengan hukum pidana.disamping itu usaha penanggulangan kejahatan lewat pembuatan undang-undang (hukum) Pidana yang ada hakikatnya merupakan bagian integral dari usaha perlindungan masyarakat. Oleh karna itu kebijakan atau politik hukum pidana juga merupakan bagian integral dari kebijakan atau politik sosial (social policy).

Kebijakan hukum pidana dapat mencakup ruang lingkup kebijakn dibidang hukum pidana materil, dibidang hukum formal dan dibidang hukum pelaksanaan pidana. Tuntutan terhadap malpraktik kedokteran sering kali kandas di tengah jalan karena sulitnya pembuktian. Dalam hal ini pihak dokter perlu membela diri dan mempertahankan hak-haknya dengan mengemukakan alsan-alasan atas penderitaannya. Baik penggungat dalam hal ini pasien, pihak dokter maupun praktisi (hakim dan jaksa) mendapat kesulitan mendapatkan kesulitan dalam mengahadapi masalah malpraktek kedokteran. Salah satunya dari sudut teknis hukum atau formulasi hukum yang tepat digunakan. Masalahnya terletak pada belum adannya hukum dan kajian hukum khusus tentang malpraktek kedokteran yang dapat di jadikan pedoman dalam menentukan dan menanggulangi adanya malpraktik di indonesia.

Kebijakan formulasi hukum pidana mengenai penanggulangan tindak pidana malpraktik ketokteran. Kejahatan terhadap pemalsuan Pasal 267 KUHP (seorang dokter yang dengan sengaja memberi surat keterangan palsu tentang ada atau tidak adanya kelemahan, atau cacat di ancam dengan pidana penjara paling lama 4 Tahun). Secara umum letak sifat melawan hukum malpraktek dibidang kesehatan terletak pada dilanggarnya kepercayaan atau amanah pasien dalam kontrak terapeutik. Kepercayaan atau amanah adalah kewajiban tenaga kesehatan untuk membuat suatu dengan sebaik- baiknya, secermat cermatnya penuh kehati-hatian, tidak cerboh, berbuat yang seharusnya di perbuat dan tidak berbuat apa yang seharusnya tidak diperbuat. Secara khusus letak sifat melawan hukum perbuatan malpraktik tidak selalu sama, bergantung pada kasus terutama syarat yang terjadi menajadi penyebab timbulnya malpraktik. Faktor sebab dalam kasus malpraktik selalu ada yaitu timbulnya akibat yang merugikan kesehatan atau nyawa pasien.

Kebijakan Penal dan Non Penal. Kebijakan Penal Kebijakan bisa di artikan sebagai suatu perilaku dari suatu pemeran untuk menetapkan suatu perbuatan sebagai bentuk tindak pidana dengan suatu tertentu, maka dalam undangn-undang dimaksud untuk menjamin kepastian hukum, menghindari penapsiran hukum dan memberikan perlindugan terhadap hak hak sosial dan ekonomi masyarakat serta menjamin keadilan.Upaya penal merupakan penanggulangan suatu kejahatan dengan menggunakan hukum pidana yang didalamnya terdapat dua masalah sentral, yaitu perbuatan apa yang seharusnya dijadikan tindak pidana dan sanksi apa yang sebaiknya 
digunakan atau dikenakan pada pelanggar. Pada hakikatnya sarana penal merupakan dari penegak hukum oleh karna itu kebijakan pendapat hukum (Law Enforcement). Penanggulangan malpraktek dapat dilakukan dengan cara menyerahkan kasus kepada penegak hukum dalam hal ini polisi, jaksa, dan untuk di proses sesuai dengan ketentuan hukum yang berlaku dimana hukuman yang dijatuhkan kepada pelaku. Menurut Moeljatno bahwa perbuatan itu merupakan suatu perbuatan yang dilarang dan di ancam dengan pidana bagi barang siapa yang melanggar larangan tersebut. Upaya penal dalam dugaan malpraktek melibatkan banyak pihak yang ikut serta dalam pembuktiannya baik dari pihak kepolisian maupun dari pihak kesehatan. Penyelesaian sengketa medik diatur dalam Undang-undang Republik Indonesia Nomor 29 Tahun 2004 Tentang Praktik Kedokteran. Apabila tindakan dokter bertentangan dengan etika dan moral serta kode etik kedokteran Indonesia (Kodeki) yang telah dibuktikan oleh Majelis Kode Etik Kedokteran (MKEK), maka bisa dikatakan malpraktik dan dapat diajukan gugatan hukum. Majelis Kehormatan Etik Kedokteran (MKEK) merupakan salah satu organisasi yang turut serta dalam prosedur penanganan dugaan malpraktik.

Kebijakan Non Penal Kebijakan non penal adalah suatu upaya penanggulangan kejahatan dengan tindak pidana. Dalam upaya non penal ini dapat juga di artikan sebagai upaya yang bersifat preventif, contohnya dapat meperbaikin kondisi-kondisi yang tertentu, dan didalamnya mencakup suatu kriminalisasi perbuatan tertentu yang menjadi gejala sosial dalam masyarakat modern.

\section{Sanksi Profesi yang Diberikan Kepada Dokter yang Melakukan Tindak Pidana yang Menyebabkan Kematian}

Pengaturan sanksi pidana secara umum diatur dalam beberapa pasal dari KUH Pidana dan dalam pengaturan secara khusus dapat dijumpai pada pasal 190 sampai dengan pasal 200 Undangundang No 36 Tahun 2009 tentang kesehatan. Oleh sebab itu Undang- undang kesehatan memungkinkan diajukan tutntutan kepada tenaga kesehatan yang melakukan kesalahan atau kelalaian ketika menjalankan tugas pelayanan kesehatan. Tuntutan itu berupa gugatan untuk membayar ganti rugi kepada korban atau keluarganya dan dasar peraturan yang terdapat dalam undang-undang tentang kesehatan yaitu pasal 58 ayat 1 yang berbunyi " setiap orang berhak menuntut ganti rugi terhadap seorang tenaga kesehatan dan penyelenggara kesehatan yang menimbulkan kerugian akibat kesalahan atau kelalaian dalam pelayanan kesehatan yang diterimanya"

Pemberian hak atau ganti rugi adalah upaya untuk memberikan perlindungan bagi setiap orang atas suatu akibat yang timbul baik fisik maupun non fisik. Jika kelalaian atau kesalahan tenaga kesehatan mungkin dapat menyebabkan kematian atau menimbulkan catat yang permanen. Kerugian fisik adalah hilangnya atau tidak berfungsinya seluruh atau sebagian orgn tubuh sedangkan yang dimaksud dengan kerugian non fidik berkaitan dengan martanat seseorang. Selain tuntutan dalam kerugian dalam perkara perdata dimungkan pula diajukan tuntutan dalam perkara pidana apabila diduga tenaga kesehatan yang melakukan malpraktek yang berkenaan dengan tuntutan dalam perkara pidana dasar peraturan yang ditegaskan dalam undang-undang tentang kesehatan. juga ada terdapat dalam pasal tertentu dalam KUH Pidana yang dapat diterapkan. secara garis besar tenaga kesehatan yang melakukan malpraktik medik dapat didakwaakan pada pasal-pasal tertentu dalam KUH Pidana yang relevan dengan unsur tindak pidana yang dilakukannya, misalnya tindak pidana pembunuhan, penganiayaan, aborsi dan membuka rahasia jabatan dan pekerjaan.

Pada Pasal 11 ayat (1) huruf b UU No. 6 Tahun 1963 tentang Tenaga Kesehatan dinyatakan dihapus oleh UU No. 23 Tahun 1992 tentang Kesehatan maka Tenaga Kesehatan ini dapat dijadikan sebagai acuan makna malpraktik yang mengidentifikasikan atau di identik malpraktik dengan melalaikan kewajiban, yang dimaksud tidak dapat melakukan sesuatu yang seharusnya dilakukan. Hukum kesehatan Tidak dapat mengurangi ketentuan-ketentuan di dalam Kitab Undang-undang Hukum Pidana dan semua Peraturan-peraturan perundang-undangan lain, maka tenaga kesehatan dapat dilakukan tindakan-tindakan administratip dalam hal sebagai berikut: 1) melalaikan semua kewajiban-kewajibannya; 2) melakukan seharusnya tidak boleh diperbuat oleh seorang tenaga kesehatan, baik mengingat sumpah jabatannya maupun mengingat 
sumpah sebagai tenaga kesehatan tersebut; 3) dapat mengabaikan sesuatu yang seharusnya dilakukan oleh tenaga kesehatan; 4) melanggar sesuatu ketentuan menurut atau berdasarkan undang-undang tersebut.

Salah satu dari akibat malpraktik terberat adalah jika sipasien meninggal dunia artinya tidak berfungsinya batang otak, berhentinya denyut nadi. Kematian ini dapat menjadi masalah besar apabila didahuluinya terjadinya malpraktik, kematian malpraktik dapat menjadi tindakan medis yang sedang berjalan atau sesaat pada jangka waktu tertentu setelah tindakan medis dilakukan, kesalahan dokter dapat diartikan sebagai berikut: 1) salah prosedur; 2) salah mengambil tindakan; 3) salah objek; 4) salah menetukan standar; 5) salah menggunakan peralatan.

Malpraktik memiliki arti yaitu setiap tindakan medis yang dilakukan oleh dokter atau orangorang dibawah pengawasan atau bisa dikatakan sebagai penyedia jasa kesehatan yang dilakukan terhadap pasienya. Seorang dokter mempunyai kedudukan yang lumayan kuat yaitu suatu profesi yang darinya banyak yang diharapkan dapat mengilangkan penyakit pasien. Namun didalam kenyataannya tidaklah demikian karena memang kadang kala timbul perbedaan perpepsi karena berlainan sudut pandang. Dimana dokter dipandang suatu dalam profesi yang dapat membantu penyelesaian seluruh persoaan tentang kesehatannya, sehingga pasien akan berharap banyak atas pertolongan- pertolongannya. Karena pasien dan masyarakat lebih melihat dari sudut hasilnya, asalkan ia sudah bekerja secara legeartis dan menurut standar profesi medis yang berlaku. Dalam undang-undang No 29 tahun 2004 tentang praktik kedokteran terdapat sanksi pidana akan tetapi hanya terpaku pada sanksi atas kesalahan sanksi atas kesalahan dalam administratif yang dilakukan dokter terhadap pasien misalnya tidak mempunyai tanda registrasi atau surat ijin praktik dan kesalahan dokter dalam memberikan pelayanan medis terhadap pasien kurang terdapat dalam undang- undang ini, padahal tolak ukur keberhasilan pelayanan medus terdapat pada keberhasilan kesembuhan atau kepuasan pasien yang memakai jasa medis.

\section{SIMPULAN}

Kebijakan dalam penanggulangan terhadap malpraktik dibidang kesehatan yang diatur dalam kitab undang-undang hukum pidana No 36 Tahun 2009 untuk memberikan perlindungan dan kepastian hukum kepada penerima pelayanan kesehatan, dokter (profesi medis) permasalahan malapraktik profesi medis sangat rumit maka perlu kebijakan untuk melakukan pencegahan terhadap tindak pidana malapraktek sangat diperlukan. Secara khusus pasal yang mengancam tindak pidana malpraktik dalam peraturan perundang-undangan mengenai malpraktek sudah cukup baik karena rumusan tindak pidana malpraktik dalam perundangan cukup lebih luas dan cakupan dari sanksi pidana yang diancam cukup memberikan efek jera bagi dokter.

Upaya yang dilakukan untuk mengatasi hambatan dalam pelaksanaan akuntabilitas pelayanan publik di Direktorat Lalu Lintas Polda Sumatera Utara antara lain: Pertama, mengembangkan program kegiatan terobosan kreatif melalui: Pertama, mengembangkan layanan Regindent Ranmor secara on line dengan berbasis web dan android. Kedua, mengembangkan layanan e-document berbasis ERI. Kedua, mengembangkan bentuk-bentuk kerjasama dengan stakeholder guna meningkatkan transparansi dan akuntabilitas pelayanan publik di dalam pelayanan Regindent Ranmor berbasis on line, antara lain: 1). bekerja sama dengan pemerintah daerah dalam integrasi sistem data base dengan data base regiden ranmor yang valid untuk dimanfaatkan secara luas untuk mendukung kepentingan instansi terkait. 2). bekerja sama dengan pihak ketiga dalam pembuatan Aplikasi Android Samsat. Untuk memudahkan masyarakat dalam bertransaksi secara online maupun dalam memberikan informasi tentang pelayanan samsat secara on line. 3). bekerja sama dengan media massa baik elektronik maupun cetak untuk meningkatkan iklan layanan masyarakat tentang program terobosan pelayanan samsat. Untuk meningkatkan informasi layanan samsat kepada masyarakat. 4). melakukan kerjasama dengan vendor yang ditunjuk untuk melakukan pendampingan operatorisasi on line. 


\section{DAFTAR PUSTAKA}

Abidin, S. Gustin, F. Pasaribu, A.H.B. \& Batubara, S.A. (2019). Tinjauan Yuridis Penjatuhan Hukuman terhadap Bidan yang Melakukan Tindakan Pidana Aborsi, Jurnal Ilmiah Penegakan Hukum, 6 (2) 2019: 155 160

Achdiat, C.M. (2004). Dinamika Etika dan Hukum Kedokteran dalam Tentang Zaman, jakarta: Penerbit buku kedokteran.

Adani, (2012). Pelajaran Hukum Pidana, Jakarta: Chazawi.

Afwina, R. (2019). Kecerdasan Emosional, Dukungan Sosial, dan Stres Kerja Dokter Residen di Rumah Sakit Umum Pusat H. Adam Malik. Journal of Education, Humaniora and Social Sciences (JEHSS). 2 (2): 229236.

Alwy, S. (2006). Kemitraan dalam Hubungan Dokter Pasien, jakarta: Rineka Cipta.

Amirudin \& Asikin, Z, (2012). Pengantar Metode Penelitian Hukum, Jakarta: Rajawali Pers.

Depdikbud, (1989). Kamus Besar Bahasa Indonesia. cet. ke-2. Jakarta: Balai Pustaka.

Guwandi, (2004). Hukum Medik, jakarta: Fakultas Kedokteran Universitas Indonesia,

Hendrik ,(2010). Etika \& Hukum Kesehatan, Jakarta: Buku kedokteran.

Johan, B. (2005). Hukum Kesehatan Pertanggung Jawaban Dokter, jakarta: Rineka Cipta.

Lasminar S, L., \& Isnaini, I. (2014). Kajian Hukum Terhadap Keterangan Ahli (Dokter) Dalam Pembuktian $\begin{array}{llll}\text { Kasus Penyalahgunaan Narkotika. JURNAL MERCATORIA, } 7(2), & 125-143 .\end{array}$ doi:https://doi.org/10.31289/mercatoria.v7i2.664

Moejatno,(1987). Asas-asas Hukum Pidana Indonesia, Jakarta: Bina Aksara.

Sadi, M. (2015). Etika Hukum Kesehatan. Jakarta: Prenadamedia Group.

Siswati, S. (2013). Etika Dan Hukum Kesehatan, jakarta; rajawali.

Sudarto, (1983). Hukum Pidana dan Perkembangan Masyaraka, Bandung: Sina

Tamba, B.I.T. (1996). Kesalahan dan Pertanggungjawab Pidana Dokter (Dalam Melakukan Perawatan), Palembang: Universitas Sriwijaya.

Triwibowo, C., (2014). Etika Hukum Kesehatan. Yogyakarta: Nuha Medika.

Undang-Undang RI Nomor 36 Tahun 2009 Tentang Kesehatan

(Abidin, dkk., 2019; Lasminar, dkk., 2014; Afwina, 2019) 